\title{
Removal of Lead (II) Ions from Aqueous Solutions onto Activated Carbon Derived from Waste Biomass
}

\author{
Murat Erdem, ${ }^{1}$ Suat Ucar, ${ }^{2}$ Selhan Karagöz, ${ }^{3}$ and Turgay Tay ${ }^{1}$ \\ ${ }^{1}$ Department of Chemistry, Faculty of Science, Anadolu University, 26470 Eskisehir, Turkey \\ ${ }^{2}$ Chemistry Program, Izmir Vocational School, Dokuz Eylül University, Buca, 35160 Izmir, Turkey \\ ${ }^{3}$ Department of Chemistry, Faculty of Science, Karabük University, Karabük, Turkey \\ Correspondence should be addressed to Murat Erdem; merdem@anadolu.edu.tr
}

Received 22 April 2013; Accepted 22 May 2013

Academic Editors: A. Avramopoulos, D. Dondi, and C. Wu

Copyright (C) 2013 Murat Erdem et al. This is an open access article distributed under the Creative Commons Attribution License, which permits unrestricted use, distribution, and reproduction in any medium, provided the original work is properly cited.

\begin{abstract}
The removal of lead (II) ions from aqueous solutions was carried out using an activated carbon prepared from a waste biomass. The effects of various parameters such as $\mathrm{pH}$, contact time, initial concentration of lead (II) ions, and temperature on the adsorption process were investigated. Energy Dispersive X-Ray Spectroscopy (EDS) analysis after adsorption reveals the accumulation of lead (II) ions onto activated carbon. The Langmuir and Freundlich isotherm models were applied to analyze equilibrium data. The maximum monolayer adsorption capacity of activated carbon was found to be $476.2 \mathrm{mg} \mathrm{g}^{-1}$. The kinetic data were evaluated and the pseudo-second-order equation provided the best correlation. Thermodynamic parameters suggest that the adsorption process is endothermic and spontaneous.
\end{abstract}

\section{Introduction}

The use of various adsorbents for the removal of heavy metal ions from aqueous solution is of great interest due to environmental concerns. The ground eggshell waste was found as an effective adsorbent for removal of anionic dye from aqueous solution [1]. The removal of cadmium using citrus fruits, apples, and grapes has been investigated [2]. It was reported that citrus peels showed the high adsorption capacity [2]. Activated carbons are widely used for the removal of heavy metal ions from aqueous solution [3-5]. The preparation of granular activated carbon (GAC) from agricultural byproducts and their use in adsorption experiments were reported by Johns et al. [3]. It was concluded that GACs produced from agricultural byproducts were more effective than commercial GACs in terms of adsorption capacity [3]. The removal of organic mercury from the wastewater has been tested using activated carbons and with an ionexchange resins (Amberlite GT73) [5]. It was reported that activated carbons showed higher adsorption capacity than the ion-exchange resin [5].

There is understandably a great effort to find low cost material to produce the activated carbon. Within the current paper, we describe our efforts to remove lead (II) ions from aqueous solution by using the activated carbon produced from soybean oil cake with chemical activation. Soybean oil cake, an agricultural byproduct, was used for the preparation of the activated carbon. The adsorption of lead (II) ions onto the activated carbon was investigated with variations in the parameters of $\mathrm{pH}$, contact time, lead (II) ions concentration and temperature. The kinetic model for lead (II) adsorption onto the activated carbon was also studied.

\section{Experimental}

2.1. Materials. The biomass (soybean oil cake) was obtained from Altinyag Oil Company, Izmir, Turkey. The sample contained $17.86 \mathrm{wt} \%$ extractives, $52.51 \mathrm{wt} \%$ hemicellulose, $2.80 \mathrm{wt} \%$ lignin, and $21.58 \mathrm{wt} \%$ cellulose. The elemental analysis of the soybean oil cake is as follows: $44.48 \mathrm{wt} \%$ C, $6.28 \mathrm{wt} \% \mathrm{H}, 8.21 \mathrm{wt} \% \mathrm{~N}, 0.54 \mathrm{wt} \% \mathrm{~S}, 40.49 \mathrm{wt} \% \mathrm{O}$ (by difference), and $5.83 \mathrm{wt} \%$ ash content. All chemicals used in the present study were of analytical grade.

2.2. Preparation of the Activated Carbon. Preparation of the activated carbon from soybean oil cake by $\mathrm{K}_{2} \mathrm{CO}_{3}$ activation 
with the impregnation ratio of 1.0 was carried out. $\mathrm{K}_{2} \mathrm{CO}_{3}$ was mixed with the soybean oil cake overnight so that reagents were fully absorbed into the biomass. The slurry was then dried at $105^{\circ} \mathrm{C}$. The impregnate material was set in a reactor and then it was carbonized at $1073.15 \mathrm{~K}$. The experimental details for the preparation of activated carbon can be found in a previous report [6]. The yield of the activated carbon was found to be $11.56 \mathrm{wt} \%$. The activated carbon, designated as SAC2, was sieved to particles $<63 \mu \mathrm{m}$ size and used for experiments. A measurement of specific surface areas of the activated carbon produced from soybean oil cake by chemical activation with $\mathrm{K}_{2} \mathrm{CO}_{3}$ has been made by $\mathrm{N}_{2}$ adsorption (at $77 \mathrm{~K}$ ), using a surface analyzer (Quantachrome Inst., Nova 2200e). Surface charge distribution of SAC2 was measured as a function of $\mathrm{pH}$ by using a Malvern Zetasizer Nanoseries. The elemental compositions of the activated carbon were determined using a LECO CHNS 932 Elemental Analyzer. The physicochemical properties of the activated carbon are as follows: $81.03 \mathrm{wt} \% \mathrm{C}, 0.53 \mathrm{wt} \% \mathrm{H}, 0.06 \mathrm{wt} \%$ $\mathrm{N}, 0.05 \mathrm{wt} \% \mathrm{~S}, 18.33 \mathrm{wt} \% \mathrm{O}$ (by difference); $0.98 \mathrm{wt} \%$ ash content, $1352.86 \mathrm{~m}^{2} \mathrm{~g}^{-1}$ specific surface area, $0.680 \mathrm{~cm}^{3} \mathrm{~g}^{-1}$ total pore volume, $0.400 \mathrm{~cm}^{3} \mathrm{~g}^{-1}$ micropore volume, and $10.05 \AA ̊$ average pore diameter.

2.3. Adsorption Experiments. The adsorption experiments were done in a batch system. Certain amount of SAC2 was added to a lead (II) nitrate solution in an Erlenmeyer flask closed with a glass stopper and the flask content stirred using a magnetic stirrer at $200 \mathrm{rpm}$ to determine the optimum values of $\mathrm{pH}$, initial concentration of lead (II) ions.

A stock solution containing $1000 \mathrm{mg} \mathrm{L}^{-1}$ of lead (II) ions was used for the adsorption experiments. The required lead (II) concentrations were provided with the dilution using deionized water. $100 \mathrm{~mL}$ of a lead (II) solution containing $50 \mathrm{mg}$ of the adsorbent in a $250 \mathrm{~mL}$ stopper conical flask was agitated at $200 \mathrm{rpm}$ in a water bath, of which temperature was controlled at desired temperature $(298.15,308.15$, and $318.15 \mathrm{~K})$. The lead (II) ions concentration of the solution was determined by atomic absorption spectrometry (Perkin Elmer A. Analyst 800 Model). The amount of lead (II) ions on the adsorbent at equilibrium was determined from the difference between the initial and final concentrations of the lead (II) solutions.

SAC2 after adsorption of lead (II) ions was dried in an oven under vacuum at $50^{\circ} \mathrm{C}$ for $24 \mathrm{~h}$, and then the lead (II) ions adsorbed SAC2 were characterized by Field Emission Scanning Electron Microscope (SEM, Carl Zeiss Ultra Plus) equipped with Energy Dispersive X-ray Spectrophotometer (EDS) analysis.

\section{Results and Discussion}

3.1. Effect of $p H$. The effect of $\mathrm{pH}$ on the lead (II) ion adsorption capacity of SAC2 was studied at $300 \mathrm{mg} \mathrm{L}^{-1}$ initial lead (II) ion concentration and at $298.15 \mathrm{~K}$. The $\mathrm{pH}$ of solutions is a factor which plays an important role in the adsorption process. Because lead (II) ions precipitate as lead (II) hydroxide at $\mathrm{pH}$ values higher than 6.7 [15], above this
$\mathrm{pH}$ value adsorption experiments were not carried out. The amphoteric nature of carbon has affected both the surface functional groups and the point of zero charge ( $\mathrm{pHPZC}$ ) of the activated carbon $[16,17]$. Cationic adsorption is favored at $\mathrm{pH}>\mathrm{pHPZC}$ and anionic adsorption is favored at $\mathrm{pH}$ $<$ pHPZC. Zeta potentials and adsorption capacity of SAC2 regarding the solution $\mathrm{pH}$ are illustrated in Figures 1(a) and 1(b), respectively. As can be seen from the figure, pHPZC of SAC2 is 6,1 and the surface was positively charged when the solution $\mathrm{pH}$ was below the $\mathrm{pH}$ of 6,1 . The magnitude of the surface charge of SAC2 was reduced while the $\mathrm{pH}$ was increased from 2 to 6 . Increased positive charge density on the sites of the activated carbon surface at low $\mathrm{pH}$ values (less than 3) blocked to come close of metal cations. On the contrary, when the $\mathrm{pH}$ value increased, the electrostatic repulsion between lead (II) ions was decreased and the surface of SAC2 became less positively charged, and the adsorption capacity of SAC2 increased. Maximum adsorption capacity was found as $244.9 \mathrm{mg} \mathrm{g}^{-1}$ at $\mathrm{pH} 6.0$.

3.2. Effect of Contact Time. A series of contact time experiments for the adsorption of lead (II) ions onto SAC2 were carried out at the initial concentration of lead (II) ions $\left(300 \mathrm{mg} \mathrm{L}^{-1}\right)$ and temperatures of $298.15,308.15$, and $318.15 \mathrm{~K}$. The effects of contact time on the adsorption process are shown in Figure 2. The adsorbed amount of lead (II) ions was increased with an increase in contact time up to $100 \mathrm{~min}$, after that there was no significant increase in the adsorption of lead (II) ions onto SAC2. At a $60 \mathrm{~min}$ of contact time, the adsorbed amounts of lead (II) ions onto SAC2 were 221.9, 232.6, and $240.2 \mathrm{mg} \mathrm{g}^{-1}$ at $298.15,308.15$, and $318.15 \mathrm{~K}$, respectively.

3.3. Effect of Initial Lead (II) Ions Concentration. The adsorption capacity of SAC2 for lead (II) ions was increased with an increase in the initial lead (II) ion concentration. Increases in the initial concentration of lead (II) ions cause the mass transfer from the aqueous phase to the solid phase. The maximum adsorption capacities were obtained at the initial lead (II) ion concentration of $500 \mathrm{mg} \mathrm{L}^{-1}$. The SEM image and X-ray spectrum of SAC2 after adsorption can be seen in Figure 3. The existence of a peak on the spectrum belonging to lead clearly proves that the accumulation of lead (II) ions onto SAC2 occurred.

3.4. Adsorption Kinetics. To investigate the adsorption process of lead (II) ions onto SAC2, the pseudo-first-order kinetic [18], pseudo-second-order kinetic [19], and intraparticle diffusion models [20] were applied to the experimental data.

The pseudo-first-order kinetic model equation is shown as

$$
\ln \left(q_{1}-q_{t}\right)=\ln q_{1}-k_{1} t
$$

where $q_{1}$ and $q_{t}$ are the amounts of lead (II) ions $\left(\mathrm{mgg}^{-1}\right)$ absorbed at equilibrium and at time $t$, respectively, and $k_{1}$ is the first-order rate constant $\left(\mathrm{min}^{-1}\right)$. 


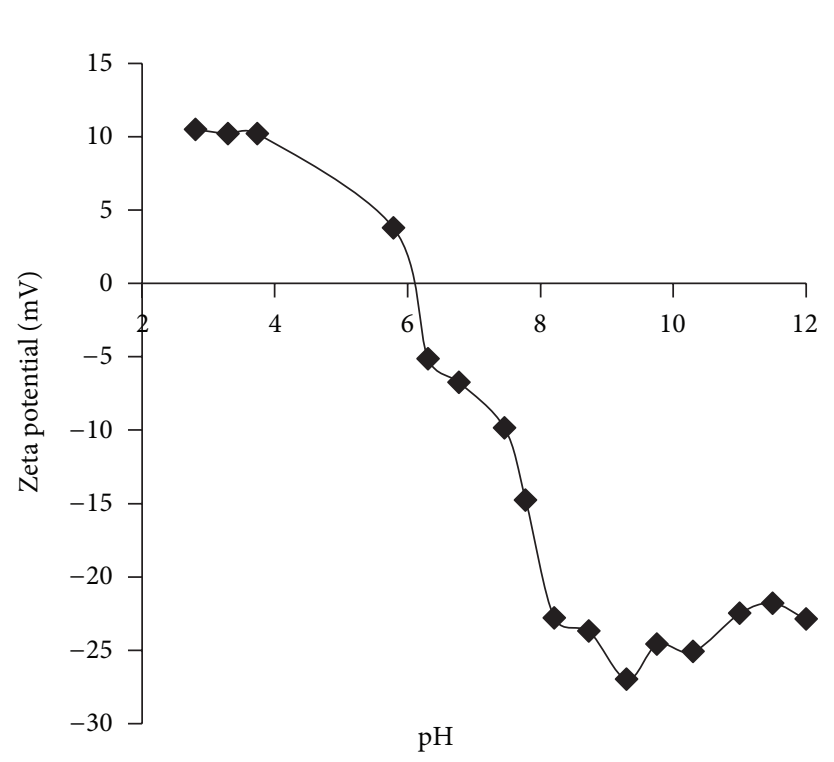

(a)

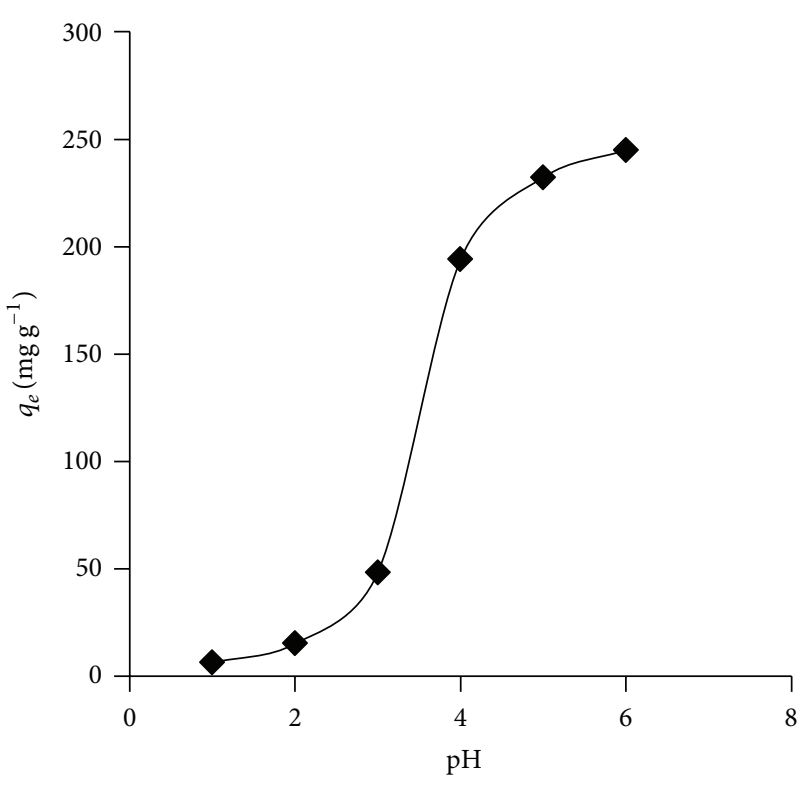

(b)

FIGURE 1: (a) Zeta potentials of SAC2 as a function of $\mathrm{pH}$, (b) effect of $\mathrm{pH}$ for the adsorption of lead (II) ions onto the activated carbon (SAC2). $\left(C_{o}=300 \mathrm{mg} \mathrm{L}^{-1} ; m=50 \mathrm{mg} ; V=100 \mathrm{~mL} ; T=25^{\circ} \mathrm{C}\right.$; agitation rate $\left.200 \mathrm{rpm}\right)$

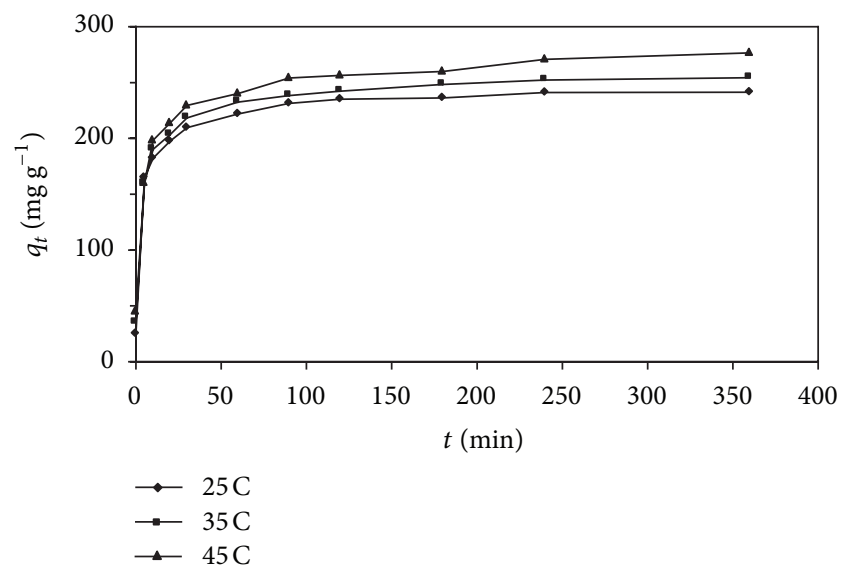

FIGURE 2: Effect of contact time for the adsorption of lead (II) ions onto the activated carbon (SAC2). $\left(C_{o}=300 \mathrm{mg} \mathrm{L}^{-1} ; m=50 \mathrm{mg}\right.$; $V=100 \mathrm{~mL} ; \mathrm{pH}=5.5$; agitation rate $200 \mathrm{rpm})$.

The pseudo-second-order kinetic model is shown as

$$
\frac{t}{q_{t}}=\frac{1}{k_{2} q_{2}^{2}}+\frac{1}{q_{2}} t,
$$

where $q_{2}$ is the maximum adsorption capacity $\left(\mathrm{mg} \mathrm{g}^{-1}\right)$ for the pseudo-second-order adsorption and $k_{2}$ is the equilibrium rate constant for the pseudo-second-order adsorption $\left(\mathrm{g} \mathrm{mg}^{-1} \mathrm{~min}^{-1}\right)$.

The intraparticle diffusion can be presented by the following equation:

$$
q_{t}=k_{p} t^{1 / 2}+C
$$

where $C$ is the intercept and $k_{p}$ is the intraparticle diffusion rate constant $\left(\mathrm{mg} \mathrm{g}^{-1} \mathrm{~min}^{-1 / 2}\right)$.

The plots of linear form of the pseudo-first-order (not shown), pseudo-second-order, and intraparticle diffusion (not shown) for the adsorption of lead (II) ions onto SAC2 were obtained at the temperatures of 298.15, 308.15, and $318.15 \mathrm{~K}$. The results of kinetic parameters are shown in Table 1. The values of the correlation coefficients of the pseudo-second-order kinetic model $\left(r_{2}^{2}\right)$ were higher than those of the $r_{1}^{2}$ of the pseudo-first-order kinetic model and $r_{p}^{2}$ of the intraparticle diffusion model. This indicates that the adsorption of lead (II) ions followed the pseudo-secondorder kinetic with the correlation coefficients of higher than 0.99 for all tested temperatures. Figure 4 gives the plots of $t / q_{t}$ versus $t$ for the adsorption process at different temperatures. With increasing the temperature, the values of the correlation coefficients of the pseudo-first-order kinetic model decreased.

3.5. Adsorption Thermodynamics. Thermodynamic parameters consisting of Gibbs free energy change $\left(\Delta G^{\circ}\right)$, enthalpy change $\left(\Delta H^{\circ}\right)$, and entropy change $\left(\Delta S^{\circ}\right)$ were calculated from the following equation:

$$
\Delta G^{\circ}=-R T \ln K_{L}
$$

where $R$ is the universal gas constant $\left(8.314 \mathrm{~J} \mathrm{~mol}^{-1} \mathrm{~K}^{-1}\right), T$ is the temperature $(\mathrm{K})$, and $K_{L}$ value was calculated using the following equation:

$$
K_{L}=\frac{q_{e}}{C_{e}}
$$




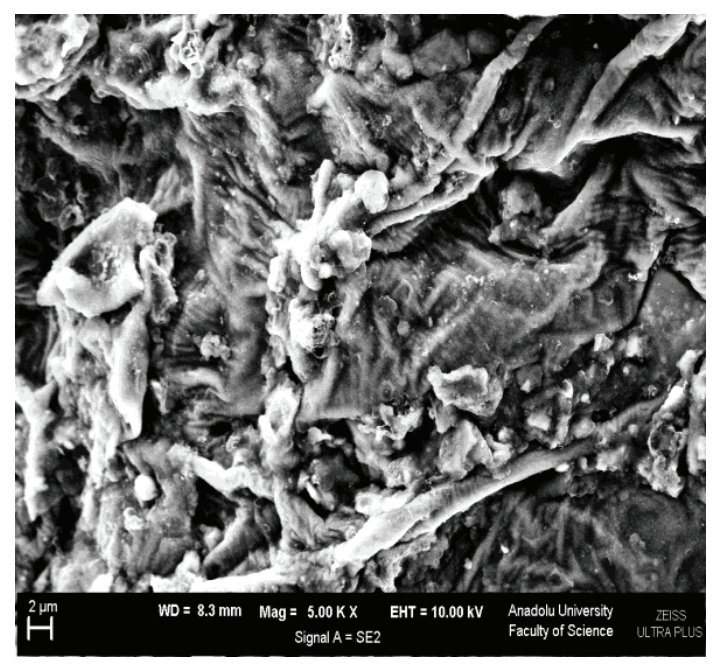

(a)

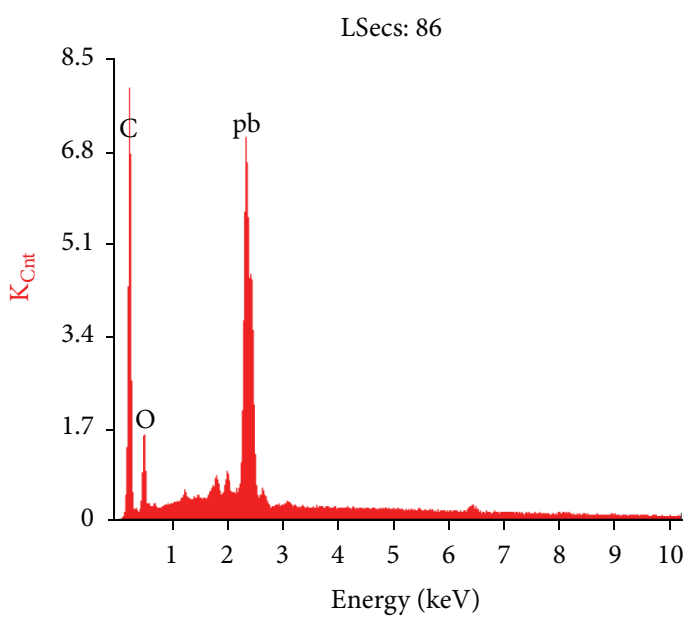

(b)

FIgURE 3: SEM image and EDS spectrum of SAC2 after lead (II) adsorption.

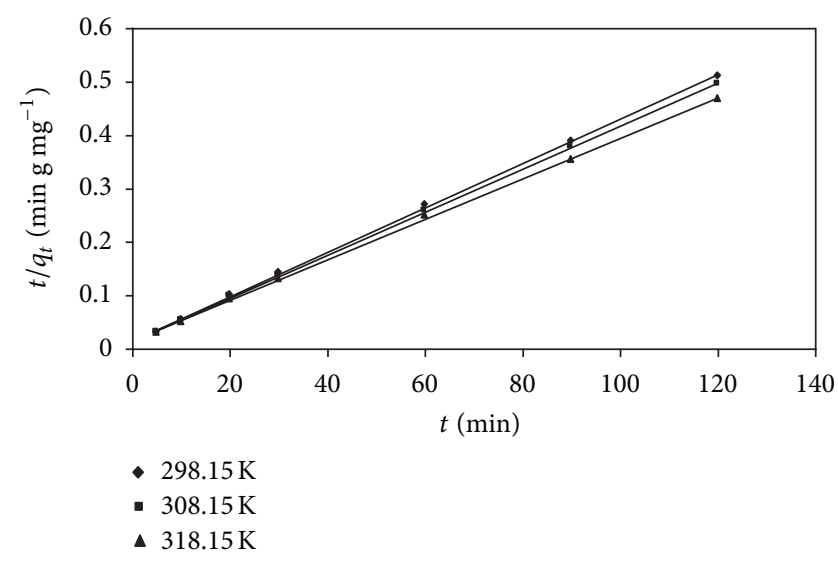

Figure 4: Pseudo-second-order kinetic plot for the adsorption of lead (II) ions onto the activated carbon (SAC2).

where $q_{e}$ and $C_{e}$ are the equilibrium concentration of lead (II) ions onto the activated carbon $\left(\mathrm{mg} \mathrm{g}^{-1}\right)$ and in the solution $\left(\mathrm{mg} \mathrm{L}^{-1}\right)$, respectively.

The enthalpy change $\left(\Delta H^{\circ}\right)$ and entropy change $\left(\Delta S^{\circ}\right)$ of the adsorption were estimated from the following equation:

$$
\ln K_{L}=\frac{\Delta S^{\circ}}{R}-\frac{\Delta H^{\circ}}{R T} .
$$

The enthalpy change $\left(\Delta H^{\circ}\right)$ and entropy change $\left(\Delta S^{\circ}\right)$ can be obtained from the slope and intercept of a Van't Hoff equation of $\left(\Delta G^{\circ}\right)$ as follows:

$$
\Delta G^{\circ}=\Delta H^{\circ}-T \Delta S^{\circ},
$$

where $\Delta G^{\circ}$ is the Gibbs free energy change (J), $R$ is the universal gas constant $\left(8.314 \mathrm{~J} \mathrm{~mol}^{-1} \mathrm{~K}^{-1}\right)$, and $T$ is the absolute temperature (K).
TABLE 1: Kinetic parameters for the adsorption of lead (II) ions onto the activated carbon (SAC2).

\begin{tabular}{lccc}
\hline Temperature $(\mathrm{K})$ & 298.15 & 308.15 & 318.15 \\
Pseudo-first-order & & & \\
$k_{1}\left(\mathrm{~min}^{-1}\right)$ & 0.023 & 0.020 & 0.017 \\
$q_{1}\left(\mathrm{mg} \mathrm{g}^{-1}\right)$ & 73.55 & 79.84 & 92.29 \\
$r_{1}^{2}$ & 0.980 & 0.928 & 0.921 \\
Pseudo-second-order & & & \\
$\quad k_{2}\left(\mathrm{~g} \mathrm{mg}^{-1} \mathrm{~min}^{-1}\right)$ & $11.6 \times 10^{-4}$ & $10.96 \times 10^{-4}$ & $9.26 \times 10^{-4}$ \\
$q_{2}\left(\mathrm{mg} \mathrm{g}^{-1}\right)$ & 238.1 & 250.0 & 263.2 \\
$r_{2}^{2}$ & 0.9995 & 0.9993 & 0.9994 \\
Intraparticle diffusion & & & \\
$k_{p}\left(\mathrm{mgg} \mathrm{min}^{-1 / 2}\right)$ & 8.7429 & 9.9775 & 11.319 \\
$C$ & 153.74 & 152.85 & 154.53 \\
$r_{p}^{2}$ & 0.9390 & 0.8791 & 0.8659 \\
\hline
\end{tabular}

Thermodynamic parameters are listed in Table 2. The Gibbs free energy change $\left(\Delta G^{\circ}\right)$ is an indicator of the degree of the spontaneity in the adsorption process. In order to provide a better adsorption, it is necessary to have a negative value for the Gibbs free energy changes $\left(\Delta G^{\circ}\right)$. The values of Gibbs free energy change $\left(\Delta G^{\circ}\right)$ of lead (II) ions adsorption were determined as $0.74,-0.99$, and $-1.40 \mathrm{~kJ} \mathrm{~mol}^{-1}$ at the temperatures of $298.73,308.73$, and $318.73 \mathrm{~K}$, respectively. These values indicate that the adsorption process is spontaneous and feasible under these conditions. The values of $\Delta G^{\circ}$ at higher temperature are more negative than those of lower temperature. This means that high efficiency of adsorption takes place at high temperatures [21]. Plot of $\ln K_{L}$ versus $1 / T$ for estimation of thermodynamic parameters for the adsorption of lead (II) ions onto SAC2 is shown in Figure 5. The positive value of $\Delta S^{\circ}$ reflects an increase in the degree of freedom of the adsorbent surface. Similar observation 


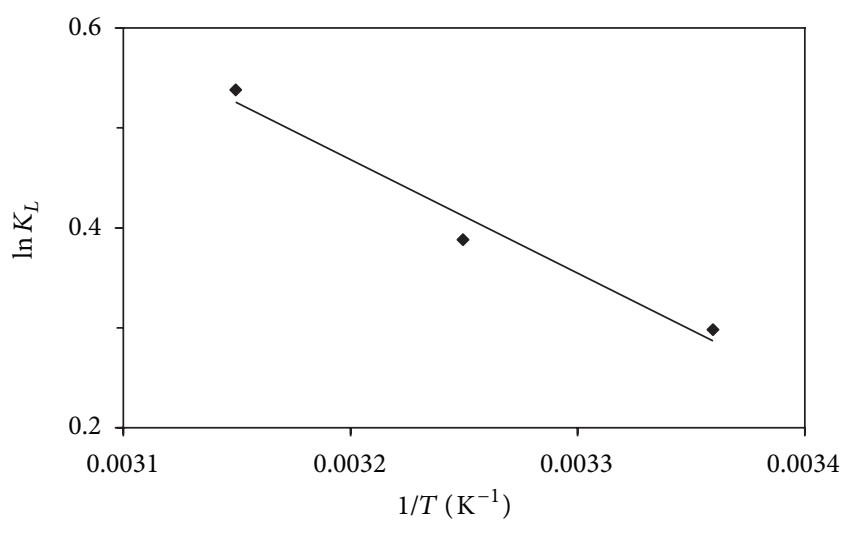

Figure 5: Plot of $\ln K_{L}$ versus 1/T for estimation of thermodynamic parameters for the adsorption of lead (II) ions onto the activated carbon (SAC2).

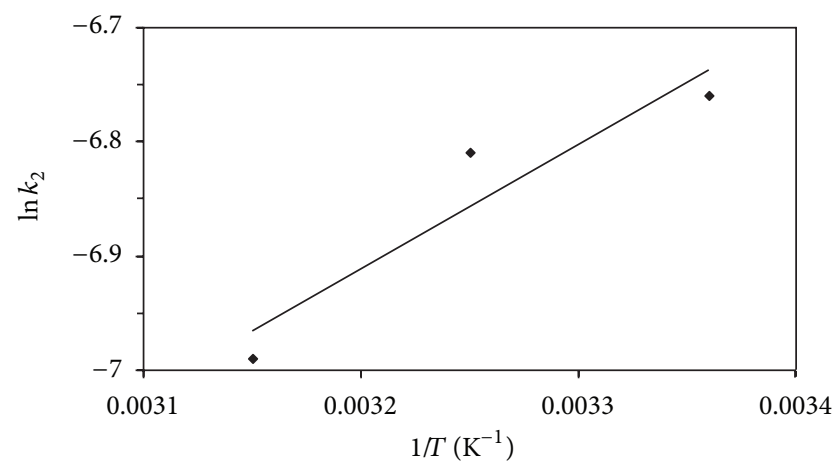

Figure 6: Plot of $\ln k_{2}$ versus $1 / T$ for estimation of activation energy for the adsorption of lead (II) ions onto the activated carbon (SAC2).

was reported in the literature [22]. The positive value of $\Delta H^{\circ}$ for the adsorption of lead (II) onto SAC2 suggests an endothermic nature of process.

Plot of $\ln k_{2}$ versus $1 / T$ for estimation of activation energy for the adsorption of lead (II) ions onto SAC2 is presented in Figure 6. Activation energy was found to be $9.02 \mathrm{~kJ} \mathrm{~mol}^{-1}$ at $308.73 \mathrm{~K}$.

3.6. Adsorption Isotherms. The adsorption data was analyzed with the use of Langmuir and Freundlich isotherms [23, 24].

Langmuir isotherm:

$$
\frac{C_{e}}{q_{e}}=\frac{1}{q_{\max } K_{L}}+\frac{C_{e}}{q_{\max }}
$$

where $q_{e}$ is the equilibrium lead (II) ions concentration on the activated carbon $\left(\mathrm{mg} \mathrm{g}^{-1}\right), C_{e}$ is the equilibrium lead (II) ions concentration in the solution $\left(\mathrm{mg} \mathrm{L}^{-1}\right), q_{\max }$ is the monolayer adsorption capacity of activated carbon $\left(\mathrm{mg} \mathrm{g}^{-1}\right)$, and $K_{L}$ is the Langmuir adsorption constant $\left(\mathrm{L} \mathrm{mg}^{-1}\right)$.

Freundlich isotherm:

$$
\log q_{e}=\log K_{F}+\frac{1}{n} \log C_{e},
$$

TABLE 2: Thermodynamic parameters calculated from the Langmuir isotherm constant, $K_{L}$, and activation energy calculated from the pseudo-second-order rate equation, $k_{2}$, for the adsorption of lead (II) ions onto the activated carbon (SAC2).

\begin{tabular}{ccccc}
\hline$T(\mathrm{~K})$ & $\begin{array}{c}E_{a} \\
\left(\mathrm{~kJ} \mathrm{~mol}^{-1}\right)\end{array}$ & $\begin{array}{c}\Delta G^{\circ} \\
\left(\mathrm{kJ} \mathrm{mol}^{-1}\right)\end{array}$ & $\begin{array}{c}\Delta H^{\circ} \\
\left(\mathrm{kJ} \mathrm{mol}^{-1}\right)\end{array}$ & $\begin{array}{c}\Delta S^{\circ} \\
\left(\mathrm{J} \mathrm{K}^{-1} \mathrm{~mol}^{-1}\right)\end{array}$ \\
\hline 298.15 & & -0.74 & & \\
308.15 & 9.02 & -0.99 & 9.46 & 34.15 \\
318.15 & & -1.40 & & \\
\hline
\end{tabular}

TABLE 3: Adsorption isotherms constants for the adsorption of lead (II) ions onto the activated carbon (SAC2) at $298.15 \mathrm{~K}$.

\begin{tabular}{lcc}
\hline \multicolumn{2}{c}{ Langmuir } \\
\hline$q_{\max }\left(\mathrm{mgg}^{-1}\right)$ & & 476.19 \\
$K_{L}\left(\mathrm{~L} \mathrm{mg}^{-1}\right)$ & 2.201 \\
$R_{L}$ & & 0.419 \\
$r_{L}^{2}$ & 0.9413 \\
\hline$n$ & Freundlich \\
\hline$K_{F}\left(\mathrm{Lg}^{-1}\right)$ & & 1.586 \\
$r_{F}^{2}$ & & 7.381 \\
\hline
\end{tabular}

where $q_{e}$ is the equilibrium lead (II) ions concentration on the activated carbon $\left(\mathrm{mg} \mathrm{g}^{-1}\right), C_{e}$ is the equilibrium lead (II) ions concentration in the solution $\left(\mathrm{mg} \mathrm{L}^{-1}\right)$, and $K_{F}\left(\mathrm{Lg}^{-1}\right)$ and $n$ are the Freundlich adsorption isotherm constants. The plots of $\log q_{e}$ versus $\log C_{e}$ for the adsorption of lead (II) ions onto the activated carbon are shown in Figure 7. The Langmuir and Freundlich isotherm parameters are given in Table 3. The $r^{2}$ value of the Freundlich model is higher than that of the Langmuir model. This shows that the Freundlich model fits better than the Langmuir model. The Freundlich isotherm model suggests heterogeneous surface [25]. A comparison for lead (II) ion adsorption capacities of activated carbons produced from various lignocellulosic materials is tabulated in Table 4 [3, 7-14]. The maximum monolayer adsorption capacity of SAC2 from Langmuir isotherms for lead (II) ions is found to be the highest in comparison with the literature $[3,7-14]$.

\section{Conclusions}

Removal of heavy metal ions from aqueous solution by the activated carbon produced from soybean oil cake has been carried out successfully. The main conclusions are as follows.

(i) The adsorption capacity for lead (II) ions was increased with an increase in the initial concentration of lead (II) ions.

(ii) The kinetic modeling of the process followed the pseudo-second-order kinetic model at all tested temperatures.

(iii) The adsorption process fitted the Freundlich model. 
TABLE 4: Comparison of adsorption capacities of activated carbons obtained from various lignocellulosic materials for lead (II) ions.

\begin{tabular}{|c|c|c|c|c|c|}
\hline \multirow{2}{*}{ Biomass } & \multirow{2}{*}{$\mathrm{pH}$} & \multirow{2}{*}{$T(\mathrm{~K})$} & \multicolumn{3}{|c|}{ Operating conditions } \\
\hline & & & $\begin{array}{l}\text { Initial concentration or range } \\
\qquad\left(\mathrm{mg} \mathrm{L}^{-1}\right)\end{array}$ & $\begin{array}{l}\text { Amount of adsorbent } \\
\left(\mathrm{g} \mathrm{L}^{-1}\right)\end{array}$ & $\begin{array}{c}\text { Adsorption capacity } \\
\left(\mathrm{mg} \mathrm{g}^{-1}\right)\end{array}$ \\
\hline Apricot stone [7] & 6.5 & 298.15 & - & 2.0 & 22.85 \\
\hline Soybean hulls [3] & 5.0 & 296.15 & 518 & 10.0 & 39.37 \\
\hline Pecan shell $[8]$ & 4.8 & - & 104 & $0.5-10.0$ & 64.2 \\
\hline Coconut shell [9] & 5.6 & 298.15 & - & 2.0 & 76.66 \\
\hline Palm shell $[10]$ & 3.0 and 5.0 & 300.15 & $100-700$ & 5.0 & 95.20 \\
\hline Sawdust [11] & 5.0 & 300.15 & $50-1000$ & 2.0 & 200.00 \\
\hline Bagasse pith [12] & $4.0-8.0$ & 303.15 & 100 & - & 200.00 \\
\hline Coir pith waste [13] & 4.0 & - & $25-100$ & - & 263.00 \\
\hline Euphorbia rigida [14] & 5.0 & 313.15 & $50-200$ & 0.8 & 279.72 \\
\hline Soybean oil cake* & 5.5 & 298.15 & $50-500$ & 0.5 & 476.2 \\
\hline
\end{tabular}

${ }^{*}$ Present study.

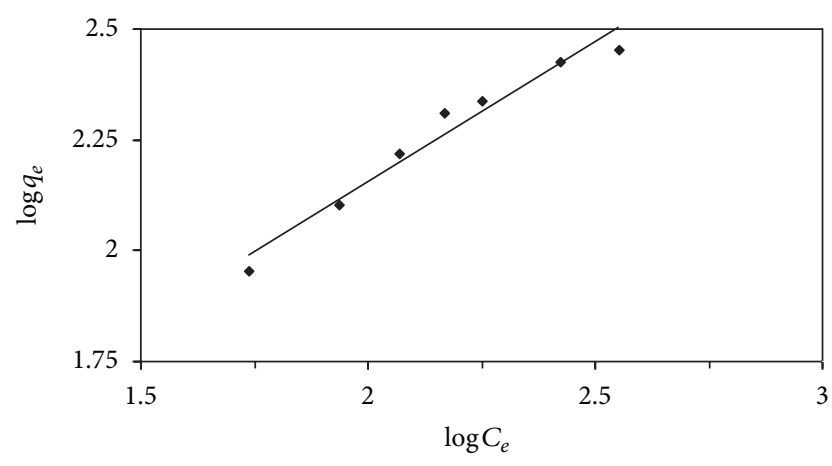

FIGURE 7: Freundlich plot for the adsorption of lead (II) ions onto the activated carbon (SAC2) at $298.15 \mathrm{~K}$.

(iv) The maximum monolayer adsorption capacity of the activated carbon was $476.2 \mathrm{mg} \mathrm{g}^{-1}$ which is quite high in comparison with the values in the literature.

Consequently, conversion of a byproduct from the vegetable oil industry to the activated carbon and its use on the adsorption of lead (II) ions from aqueous solution are very important from the viewpoint of economic and environmental aspects.

\section{References}

[1] W. T. Tsai, K. J. Hsien, H. C. Hsu, C. M. Lin, K. Y. Lin, and C. H. Chiu, "Utilization of ground eggshell waste as an adsorbent for the removal of dyes from aqueous solution," Bioresource Technology, vol. 99, no. 6, pp. 1623-1629, 2008.

[2] S. Schiewer and S. B. Patil, "Pectin-rich fruit wastes as biosorbents for heavy metal removal: equilibrium and kinetics," Bioresource Technology, vol. 99, no. 6, pp. 1896-1903, 2008.

[3] M. M. Johns, W. E. Marshall, and C. A. Toles, "Agricultural byproducts as granular activated carbons for adsorbing dissolved metals and organics," Journal of Chemical Technology and Biotechnology, vol. 71, no. 2, pp. 131-140, 1998.
[4] N. Kannan and G. Rengasamy, "Comparison of cadmium ion adsorption on various activated carbons," Water, Air, and Soil Pollution, vol. 163, no. 1-4, pp. 185-201, 2005.

[5] M. Velicu, H. Fu, R. P. S. Suri, and K. Woods, "Use of adsorption process to remove organic mercury thimerosal from industrial process wastewater," Journal of Hazardous Materials, vol. 148, no. 3, pp. 599-605, 2007.

[6] T. Tay, S. Ucar, and S. Karagöz, "Preparation and characterization of activated carbon from waste biomass," Journal of Hazardous Materials, vol. 165, no. 1-3, pp. 481-485, 2009.

[7] M. Kobya, E. Demirbas, E. Senturk, and M. Ince, "Adsorption of heavy metal ions from aqueous solutions by activated carbon prepared from apricot stone," Bioresource Technology, vol. 96, no. 13, pp. 1518-1521, 2005.

[8] R. R. Bansode, J. N. Losso, W. E. Marshall, R. M. Rao, and R. J. Portier, "Adsorption of metal ions by pecan shell-based granular activated carbons," Bioresource Technology, vol. 89, no. 2, pp. 115-119, 2003.

[9] Y. Kikuchi, Q. Qian, M. Machida, and H. Tatsumoto, "Effect of $\mathrm{ZnO}$ loading to activated carbon on $\mathrm{Pb}$ (II) adsorption from aqueous solution," Carbon, vol. 44, no. 2, pp. 195-202, 2006.

[10] G. Issabayeva, M. K. Aroua, and N. M. N. Sulaiman, "Removal of lead from aqueous solutions on palm shell activated carbon," Bioresource Technology, vol. 97, no. 18, pp. 2350-2355, 2006.

[11] R. Ayyappan, A. C. Sophia, K. Swaminathan, and S. Sandhya, "Removal of $\mathrm{Pb}(\mathrm{II})$ from aqueous solution using carbon derived from agricultural wastes," Process Biochemistry, vol. 40, no. 3-4, pp. 1293-1299, 2005.

[12] K. A. Krishnan and T. S. Anirudhan, "Uptake of heavy metals in batch systems by sulfurized steam activated carbon prepared from sugarcane bagasse pith," Industrial and Engineering Chemistry Research, vol. 41, no. 20, pp. 5085-5093, 2002.

[13] K. Kadirvelu and C. Namasivayam, "Agricultural by-product as metal adsorbent: sorption of lead(II) from aqueous solution onto coirpith carbon," Environmental Technology, vol. 21, no. 10, pp. 1091-1097, 2000.

[14] Ö. Gerçel and H. F. Gerçel, "Adsorption of lead(II) ions from aqueous solutions by activated carbon prepared from biomass plant material of Euphorbia rigida," Chemical Engineering Journal, vol. 132, no. 1-3, pp. 289-297, 2007.

[15] M. Momčilović, M. Purenović, A. Bojić, A. Zarubica, and M. Randelovid, "Removal of lead(II) ions from aqueous solutions 
by adsorption onto pine cone activated carbon," Desalination, vol. 276, no. 1-3, pp. 53-59, 2011.

[16] L. R. Radovic, I. F. Silva, J. I. Ume, J. A. Menéndez, C. A. Leon Y Leon, and A. W. Scaroni, "An experimental and theoretical study of the adsorption of aromatics possessing electron-withdrawing and electron-donating functional groups by chemically modified activated carbons," Carbon, vol. 35, no. 9, pp. 1339-1348, 1997.

[17] D. Savova, N. Petrov, M. F. Yardim et al., "The influence of the texture and surface properties of carbon adsorbents obtained from biomass products on the adsorption of manganese ions from aqueous solution," Carbon, vol. 41, no. 10, pp. 1897-1903, 2003.

[18] S. Lagergen, "Zur theorie der sogenannten adsorption geloster stoffe," Kungliga Svenska Vetenskapsakademiens Handlingar, vol. 24, no. 4, pp. 1-39, 1898.

[19] Y. S. Ho and G. McKay, "Kinetic models for the sorption of dye from aqueous solution by wood," Process Safety and Environmental Protection, vol. 76, no. 2, pp. 183-191, 1998.

[20] W. J. Weber and J. C. Morris, "Kinetics of adsorption on carbon from solution," Journal of the Sanitary Engineering Division, vol. 89, no. 2, pp. 31-60, 1963.

[21] X. Y. Yu, T. Luo, Y. X. Zhang et al., "Adsorption of lead(II) on O2-plasma-oxidized multiwalled carbon nanotubes: thermodynamics, kinetics, and desorption," ACS Applied Materials and Interfaces, vol. 3, no. 7, pp. 2585-2593, 2011.

[22] Z. Z. Chowdhury, S. M. Zain, R. A. Khan, R. F. Rafique, and K. Khalid, "Batch and fixed bed adsorption studies of lead (II) cations from aqueous solutions onto granular activated carbon derived from mangostana garcinia shell," Bioresources, vol. 7, no. 3, pp. 2895-2915, 2012.

[23] I. Langmuir, "The adsorption of gases on plane surfaces of glass, mica and platinum," The Journal of the American Chemical Society, vol. 40, no. 9, pp. 1361-1403, 1918.

[24] H. M. F. Freundlich, "Over the adsorption in solution," The Journal of Physical Chemistry, vol. 57, pp. 385-471, 1906.

[25] A. W. Adamson, Physical Chemistry of Surface, Interscience Publication, New York, NY, USA, 1960. 

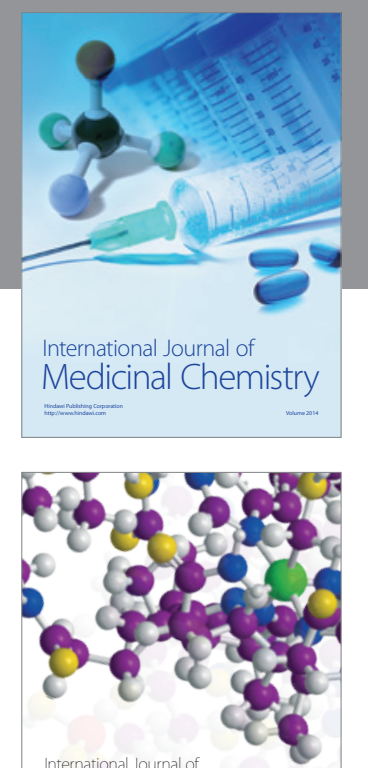

\section{Carbohydrate} Chemistry

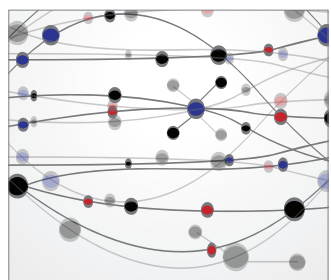

The Scientific World Journal
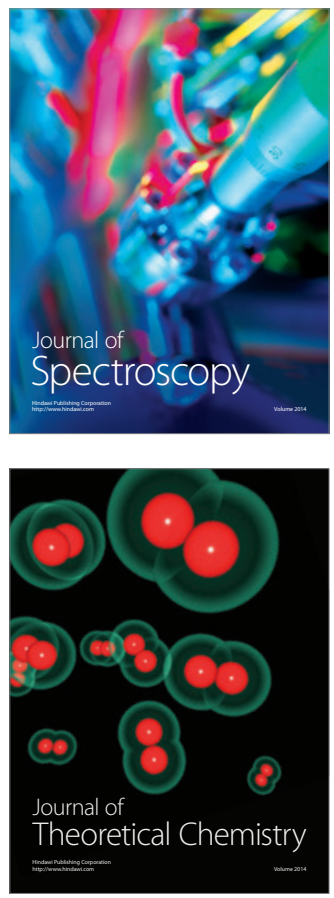
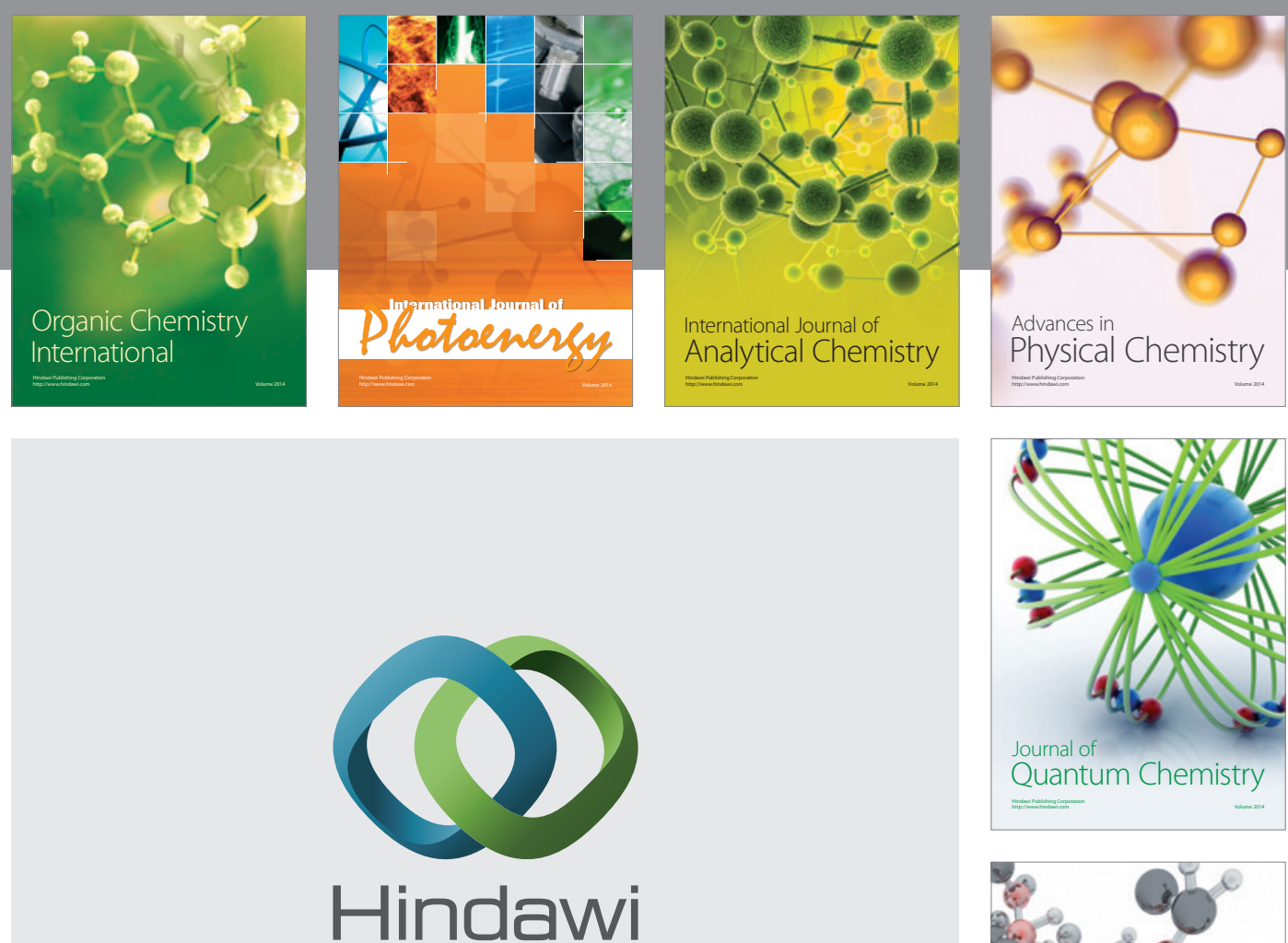

Submit your manuscripts at

http://www.hindawi.com

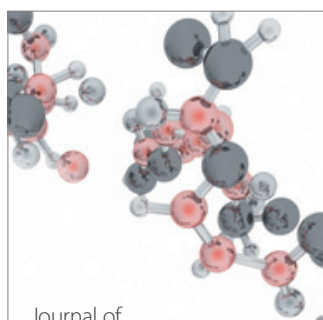

Analytical Methods

in Chemistry

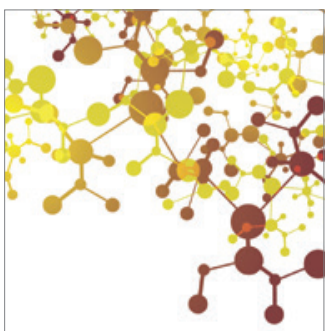

Journal of

Applied Chemistry

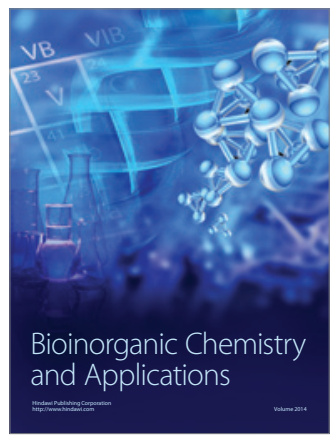

Inorganic Chemistry
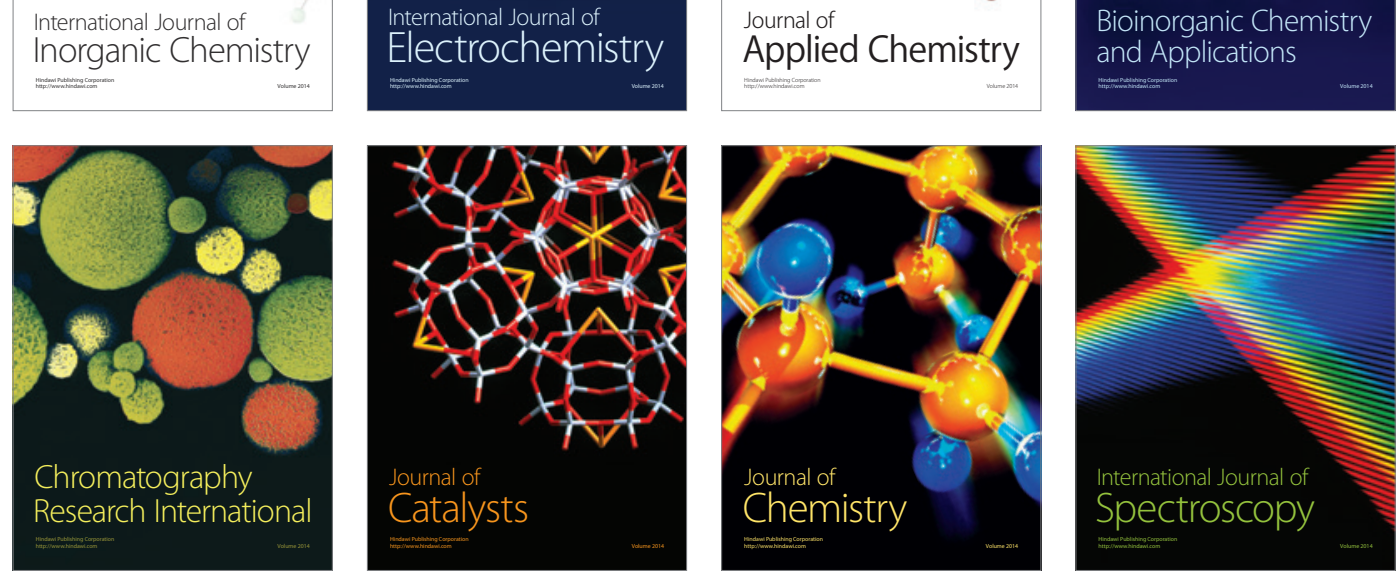